\title{
PENGUNGKAPAN DIRI (SELF DISCLOSURE) PADA ORANG DENGAN HIV/AIDS (ODHA)
}

\author{
I Wayan Candra, Ayu Gede Intan Astri Dewi \\ Politeknik Kesehatan Denpasar \\ Email: suryabhrihaspathi@gmail.com
}

\begin{abstract}
HIV/AIDS is public health problems the largest in the world today.HIV/AIDS there are in almost all countries in the world without exception including indonesia. A person who is infected with HIVIAIDS or living still have fear to express status disease because of the stigma the negative of the community of HIVIAIDS. The disclosure of self ( self disclosure) is the type a communication that revealed information about yourself to others who actively hidden. Self disclosure can help someone communicate with others, increase the confidence of ourselves and relation of being more familiar. Self disclosure also be able to deliver the guilt and anxious. This study attempts to know the level disclosure everybody with HIVIAIDS in health foundation Bali.The kind of research this is research descriptive. This research used the cross sectional. Sampling techniques used is purposive sampling. The total sample of the research is 30 people. Using techniques data collection jourard self disclosure quitionaire. The result showed 5 respondents (16.7\%) has a high disclosure themselves, 19 respondents $(63.3 \%)$ have a themselves are disclosure, and 6 respondents (20\%) have a low disclosure themselves. Most of the disclosure themselves (self disclosure) among respondents is the disclosure themselves are about 19 respondents (63.3\%).
\end{abstract}

Key words: Self disclosure, ODHA

\section{ABSTRAK}

HIVIAIDS merupakan masalah kesehatan masyarakat terbesar di dunia dewasa ini. HIV/AIDS terdapat hampir di semua negara di dunia tanpa kecuali termasuk Indonesia. Orang yang sudah terinfeksi HIVIAIDS atau ODHA masih mempunyai ketakutan untuk mengungkapkan status penyakitnya karena adanya stigma negatif dari masyarakat mengenai HIV/AIDS. Pengungkapan diri (self disclosure) merupakan jenis komunikasi yang mengungkapkan informasi tentang diri sendiri kepada orang lain yang secara aktif disembunyikan. Self disclosure dapat membantu seseorang berkomunikasi dengan orang lain, meningkatkan kepercayaan diri serta hubungan menjadi lebih akrab. Self disclosure juga dapat melepaskan perasaan bersalah dan cemas. Penelitian ini bertujuan untuk mengetahui tingkat pengungkapan diri orang dengan HIV/AIDS di Yayasan Kesehatan Bali. Jenis penelitian ini adalah penelitian deskriptif. Penelitian ini menggunakan pendekatan cross sectional. Teknik sampling yang digunakan adalah purposive sampling. Jumlah sampel dalam penelitian ini adalah 30 orang. Teknik pengumpulan data menggunakan Jourard Self Disclosure Quitionaire. Hasil penelitian menunjukkan 5 responden (16.7\%) memiliki tingkat pengungkapan diri tinggi, 19 responden (63.3\%) mempunyai tingkat pengungkapan diri sedang, dan 6 responden (20\%) mempunyai tingkat pengungkapan diri rendah. Sebagian besar tingkat pengungkapan diri (self disclosure) pada responden adalah tingkat pengungkapan diri sedang sebanyak 19 responden (63.3\%).

Kata kunci : Pengungkapan diri, ODHA 


\section{PENDAHULUAN}

HIV/AIDS merupakan masalah kesehatan masyarakat terbesar di dunia dewasa ini. HIV/AIDS terdapat hampir di semua negara di dunia tanpa kecuali termasuk Indonesia. Pada tahun 80-an HIV/AIDS menyerang terutama orang dewasa dengan perilaku seks menyimpang, sekarang ini HIV/AIDS telah menulari bayi dan anak-anak. Di Afrika AIDS merupakan penyakit keluarga. Upaya untuk menanggulangi HIV/AIDS sudah dilakukan, namun sampai saat ini usaha tersebut belum membawa hasil yang memuaskan. Obat ataupun vaksin yang mujarab untuk mengobati ataupun mencegah AIDS belum ditemukan (Irianto, 2014).

World Health Organization (WHO) (2015) melaporkan sampai saat ini HIV/AIDS telah menelan lebih dari 34 juta jiwa. Pada tahun 2014, 1.2 juta orang meninggal karena HIV/AIDS. Ada 36.900.000 orang yang hidup dengan HIV pada akhir tahun 2014, dengan 2 juta orang yang baru terinfeksi HIV. Sejak tahun 2005 sampai September 2015, di Indonesia terdapat kasus HIV/AIDS sebanyak 184.929 kasus yang didapat dari laporan layanan konseling dan tes HIV. Faktor risiko penularan HIV/AIDS tertinggi adalah hubungan seks tidak aman pada heteroseksual
$46,2 \%$, penggunaan jarum suntik tidak steril 3,4\%, homoseksual 24,4\%. Jumlah kasus HIV/AIDS tertinggi yaitu di DKI Jakarta 38.464 kasus, diikuti Jawa Timur 24.104 kasus, Papua 20.147 kasus, Jawa Barat 17.075 kasus dan yang kelima adalah Bali $\quad 9.637 \quad$ kasus (Metrotvnews.com, 2015). Jumlah kasus HIV/AIDS di Bali tahun 2015 adalah 2442 kasus dengan rincian 2410 orang masih hidup dan 32 orang sudah meninggal. Dari jumlah 2442 orang pasien HIV/AIDS, 1467 orang berjenis kelamin laki-laki dan 975 orang perempuan (Dinas Kesehatan Provinsi Bali,2016). Hasil studi pendahuluan yang dilakukan peneliti ke Yayasan Kesehatan Bali, diperoleh data total jumlah klien ODHA dampingan Yayasan Kesehatan Bali sampai dengan Februari 2015 yaitu 275 orang. Dari 275 orang tersebut yang berjenis kelamin perempuan sebanyak 241 orang dan lakilaki 34 orang.

Sampai saat ini masyarakat acuh tak acuh bahkan stigma mereka semakin negatif. Persepsi negatif masyarakat terhadap pasien HIV/AIDS berdasarkan stimulus yang mereka terima. Stimulus ini salah satunya adalah melalui informasi yang masyarakat terima tentang HIV/AIDS sehingga terbentuk stigma dan diskriminasi masyarakat 
terhadap pasien HIV/AIDS (Hermawati, 2011).

Suriana \& Dewi (2013) menemukan bahwa orang yang sudah terinfeksi HIV/AIDS atau ODHA masih mempunyai ketakutan untuk mengungkapkan status penyakitnya karena adanya stigma negatif dari masyarakat mengenai HIV/AIDS. Masyarakat beranggapan negatif terhadap HIV/AIDS, sehingga ODHA cenderung menutup diri dari lingkungan masyarakat tanpa memberitahu keadaan yang sebenarnya dan hanya dengan orang-orang tertentu ODHA mau berbagi. Hanya sedikit ODHA yang mau mengungkapkan diri kepada orang lain. Menurut Devito (2011) self disclosure atau pengungkapan diri merupakan jenis komunikasi yang mengungkapkan informasi tentang diri sendiri kepada orang lain yang secara aktif disembunyikan. Jourard mengartikan self disclosure sebagai tindakan baik secara verbal maupun non verbal, mengungkapkan aspek-aspek tentang diri sendiri kepada orang lain. Kata lainnya, pengungkapan diri adalah menyampaikan informasi baik secara verbal atau non verbal, lisan maupun tulisan tentang keunikan diri pribadi seseorang, pilihan-pilihan yang dibuat, dan bagian-bagian yang sulit dapat diukur dari dirinya, misalnya perasaannya.

Gainau (2009) menemukan bahwa individu yang mampu dalam pengungkapan diri (self disclosure) akan dapat mengungkapkan diri secara tepat, terbukti mampu menyesuaikan diri (adaptif), lebih percaya diri sendiri, lebih kompeten, dapat diandalkan, lebih mampu bersikap positif, percaya terhadap orang lain, lebih objektif, dan terbuka. Sebaliknya individu yang kurang mampu dalam pengungkapan diri (self disclosure) terbukti tidak mampu menyesuaikan diri, kurang percaya diri, timbul perasaan takut, cemas, merasa rendah diri, dan tertutup.

Selama ini HIV/AIDS dikaitkan dengan penyakit kutukan, sehingga ketika seseorang terinfeksi penyakit tersebut tidak jarang masyarakat mengecap bahwa tindakan yang dilakukan adalah buruk dan kadang tidak beragama. Selain itu masyarakat yang menjauh pada ODHA dengan alasan ketakutan akan penularan penyakit tersebut. Itulah sebabnya ODHA cenderung menutup diri dari masyarakat maupun keluarganya sendiri (Hemawati, 2009). Suriana \& Dewi (2011) menemukan bahwa beberapa ODHA mampu melakukan pengungkapan diri. Hasil yang didapat oleh ODHA setelah 
melakukan pengungkapan diri mengenai status HIV-nya kepada keluarganya adalah keluarga memberi dukungan yang positif kepada ODHA untuk selalu melakukan pengobatan, meskipun pada awal pengungkapan diri sempat mengalami pengucilan oleh keluarga. Pengungkapan diri yang dilakukan ODHA karena mempunyai dorongan dan tujuan tertentu. Setelah melakukan pengungkapan diri kepada keluarga, hubungan ODHA dengan keluarga tidak mengalami perubahan, sama seperti sebelum terkena HIV positif. Manfaat dari pengungkapan diri yang dirasakan oleh subjek kepada orang-orang terdekatnya yaitu subjek merasa tenang, beban pikiran mengenai penyakitnya berkurang, bisa membagi pengalaman kepada yang mendengarkan ceritanya supaya berhati-hati-hati dan tidak tertular seperti dirinya.

Penelitian ini bertujuan: untuk mengetahui tingkat pengungkapan diri (self disclosure) pada orang dengan HIV/AIDS (ODHA) di Yayasan Kesehatan Bali tahun 2016. Secara khusus tujuan penelitian ini adalah: untuk mengidentifikasi berbagai dimensi pengungkapan diri orang dengan HIV/AIDS (ODHA), mengidentifikasi pengungkapan diri ODHA berdasarkan usia, jenis kelamin, dan status perkawinan.

\section{METODE}

Penelitian ini adalah penelitian deskriptif dengan pendekatan terhadap subyek penelitian cross sectional. Populasi dalam penelitian ini adalah semua klien ODHA di Yayasan Kesehatan Bali tahun 2016. Penelitian ini menggunakan teknik non probability sampling dengan teknik purposive sampling. Jumlah sampel dalam penelitian ini sebanyak 30 orang. Jenis data yang dikumpulkan adalah data primer yang diperoleh langsung dari responden dengan pengisian instrumen pengumpulan data, serta data sekunder diperoleh dari rekam medik klien di Yayasan Kesehatan Bali mengenai data pasien.

Instrumen pengumpulan data menggunakan Jourard Self Disclosure Quitionaire yang mengacu pada teori yang dikemukakan oleh Sidney $M$. Jourard pada tahun 1958. Instrumen pengungkapan diri ini terdiri atas 12 item yang dapat dikelompokan menjadi dimensi dimensi keluasan (breadth) diwakili oleh item pernyataan, yang meliputi aspek: sikap dan pendapat, selera dan minat, bekerja atau belajar, uang, kepribadian, dan fisik. Dimensi kedalaman (depth) diwakili oleh pilihan 
jawaban responden mengenai penilaian pengungkapan diri atas item-item pernyataan,yaitu tdk (tidak), gb (garis besar), lkp (lengkap), dan slh (salah). Dimensi target dan sasaran (target person) diwakili oleh pilihan jawaban responden mengenai target atau sasaran yang dipilih untuk mengungkapkan atas item-item pernyataan tersebut, yaitu ayah, ibu, teman laki-laki, teman perempuan dan pasangan. Instrumen pengungkapan diri disusun dalam bentuk skala rating, responden menjawab dengan memberikan nilai dari yang besar sampai yang kecil pada tiap-tiap item. Teknik analisa data yang digunakan adalah teknik analisa data deskriptif.

\section{HASIL DAN PEMBAHASAN}

Terlebih dahulu diuraikan karakteristik responden berdasarkan usia, jenis kelamin, dan status perkawinan.

Tabel 1. Distribusi Frekuensi Usia Responden

\begin{tabular}{ccc}
\hline Usia & $\mathrm{f}$ & $\%$ \\
\hline $20-30$ tahun & 9 & 30 \\
$31-59$ tahun & 21 & 70 \\
$>60$ tahun & 0 & 0 \\
\hline Jumlah & 30 & 100 \\
\hline
\end{tabular}

Tabel 1 menunjukkan bahwa dari 30 responden, sebagian besar sebanyak 21 responden $(70 \%)$ berada pada rentang usia 31-59 tahun

Tabel 2. Distribusi Frekuensi Jenis Kelamin Responden

\begin{tabular}{ccc}
\hline Jenis Kelamin & $\mathrm{f}$ & $\%$ \\
\hline Laki - laki & 14 & 46.7 \\
Perempuan & 16 & 53.3 \\
\hline Jumlah & 30 & 100 \\
\hline
\end{tabular}

Tabel 2 menunjukkan bahwa dari 30 responden, sebagian besar responden sebanyak 16 responden (53,3\%) berjenis kelamin perempuan. 
Tabel 3. Distribusi Frekuensi Status Perkawinan Responden

\begin{tabular}{ccc}
\hline Status Perkawinan & $\mathrm{f}$ & $\%$ \\
\hline Belum menikah & 5 & 16.7 \\
Sudah menikah & 25 & 83.3 \\
\hline Jumlah & 30 & 100 \\
\hline
\end{tabular}

Tabel 3 menunjukkan bahwa dari 30 dimensi pengungkapan diri, responden, sebagian besar sebanyak 25 pengungkapan diri berdasarkan usia, responden $(83,3 \%)$ sudah menikah. jenis kelamin, dan status perkawinan.

Berikut disajikan hasil analisa data yang meliputi tingkat pengungkapan diri,

Tabel 4. Distribusi Frekuensi Pengungkapan Diri Responden

\begin{tabular}{ccc}
\hline Pengungkapan Diri (Self Disclosure) & $\mathrm{f}$ & $\%$ \\
\hline Rendah & 6 & 20 \\
Sedang & 19 & 63.3 \\
Tinggi & 5 & 16.7 \\
\hline Jumlah & 30 & 100 \\
\hline
\end{tabular}

Tabel 4 menunjukkan bahwa sebagian besar responden sebanyak 19 responden (63.3\%) mempunyai tingkat pengungkapan diri (self disclosure) sedang. Hasil penelitian ini sejalan dengan penelitian yang dilakukan oleh Nurhayati (2011) yang menemukan bahwa ODHA yang menjalani pendampingan di kelompok Warga Peduli AIDS (WPA) di Kelurahan Kebon Pisang, Kecamatan Sumur Bandung, Kota Bandung memiliki tingkat pengungkapan diri pada kategori sedang, yang berarti ODHA cukup terbuka dengan mengungkapkan dirinya secara garis besar kepada orang lain.

Menurut Gainau (2009) individu yang mampu dalam keterbukaan diri (self disclosure) akan dapat mengungkapkan diri secara tepat, terbukti mampu menyesuaikan diri (adaptive), lebih percaya diri sendiri, lebih kompeten, dapat diandalkan, lebih mampu bersikap positif, percaya terhadap orang lain, lebih objektif, dan terbuka. Sebaliknya individu yang kurang mampu dalam keterbukaan diri (self disclosure) terbukti tidak mampu menyesuaikan diri, kurang percaya diri, timbul perasaan 
takut, cemas, merasa rendah diri, dan tertutup.

Menurut peneliti seseorang yang mampu dalam pengungkapan diri akan lebih mudah bergaul dan dapat berinteraksi sosial dengan baik. Orang yang terbuka biasanya memiliki teman yang lebih banyak dan lebih ceria daripada orang yang cenderung tertutup. Pengungkapan diri juga memberi manfaat perbaikan secara psikologis, seseorang yang mengalami frustasi atau kecewa akan mudah bangkit kembali apabila menceritakan masalahnya kepada orang lain.

Devito (2011) mengungkapkan keuntungan yang akan diperoleh jika individu mau mengungkapkan informasi kepada orang lain, diantaranya mengurangi beban. Jika individu menyimpan rahasia dan tidak mengungkapkannya kepada orang lain, maka akan terasa berat sekali memikulnya, dengan adanya pengungkapan diri individu akan merasakan beban itu terkurangi sehingga orang tersebut ringan beban masalah yang dihadapinya. Dalam penilitian ini responden sudah mau mengungkapkan informasi kepada orang lain, walaupun secara garis besar saja, hanya sedikit responden yang mengungkapkan informasi kepada orang lain secara lengkap.

Tabel 5. Distribusi Frekuensi Dimensi Breadth (Keluasan) Pengungkapan Diri Responden

\begin{tabular}{|c|c|c|c|c|c|c|c|c|}
\hline \multirow{3}{*}{ Breadth (Keluasan) } & \multicolumn{8}{|c|}{ Hasil } \\
\hline & \multicolumn{2}{|c|}{ Tinggi } & \multicolumn{2}{|c|}{ Sedang } & \multicolumn{2}{|c|}{ Rendah } & \multicolumn{2}{|c|}{ Total } \\
\hline & $\mathrm{f}$ & $\%$ & $\mathrm{f}$ & $\%$ & $\mathrm{f}$ & $\%$ & $\mathrm{f}$ & $\%$ \\
\hline Sikap dan pendapat & 1 & 3.3 & 2 & 6.7 & 1 & 3.3 & 4 & 13.3 \\
\hline Selera dan minat & 1 & 3.3 & 6 & 20 & 2 & 6.7 & 9 & 30 \\
\hline Bekerja atau belajar & 0 & 0 & 5 & 16.7 & 1 & 3.3 & 6 & 20 \\
\hline Keuangan & 1 & 3.3 & 4 & 13.3 & 0 & 0 & 5 & 16.7 \\
\hline Kepribadian & 0 & 0 & 2 & 6.7 & 2 & 6.7 & 4 & 13.3 \\
\hline Fisik & 2 & 6.7 & 1 & 3.3 & 0 & 0 & 3 & 10.0 \\
\hline$\sum$ & 5 & 16.7 & 19 & 63.3 & 6 & 20 & 30 & 100 \\
\hline
\end{tabular}

Tabel 5 menunjukkan bahwa sebagian besar sebanyak 8 responden $(26.7 \%)$ dimensi breadth (keluasan materi) pengungkapan diri yang berada dalam kategori sedang adalah pada selera dan minat. Hal ini sejalan dengan penelitian yang dilakukan oleh Nurhayati (2011) yang menemukan bahwa ODHA yang 
menjalani pendampingan di kelompok Warga Peduli AIDS (WPA) di Kelurahan Kebon Pisang, Kecamatan Sumur Bandung, Kota Bandung lebih banyak mengungkapkan dirinya mengenai selera dan minat atau hal - hal yang disenangi kepada orang lain.

Menurut peneliti ODHA lebih terbuka mengenai selera dan minatnya karena hal tersebut sudah biasa diungkapkan kepada orang lain. ODHA di Yayasan Kesehatan Bali belum terbuka mengenai hal - hal yang lebih pribadi seperti tentang keuangan, kepribadian atau status kesehatannya. ODHA hanya dapat mengungkapkan mengenai dirinya tentang hal- hal yang bersifat umum tidak mengenai hal - hal yang lebih bersifat pribadi. Menurut Jourard (1968) seseorang lebih mungkin mengungkapkan suatu informasi diri tentang pekerjaan dan hobi daripada tentang kehidupan seks atau situasi keuangan. Umumnya semakin bersifat pribadi dan semakin negatif suatu topik, makin kecil kemungkinan pengungkapannya.Hal ini bisa terjadi karena topik yang bersifat pribadi untuk mengungkapkannya memerlukan suatu kepercayaan. Topik negatif agar bisa diungkapkan segera memerlukan keberanian yang kuat untuk menanggung risiko akibat dari pengungkapan topik negatif tersebut.

Tabel 6. Distribusi Frekuensi Dimensi Depth (Kedalaman) Pengungkapan Diri Responden

\begin{tabular}{|c|c|c|c|c|c|c|c|c|}
\hline \multirow{3}{*}{ Depth (Kedalaman) } & \multicolumn{6}{|c|}{ Hasil } & & \\
\hline & \multicolumn{2}{|c|}{ Tinggi } & \multicolumn{2}{|c|}{ Sedang } & \multicolumn{2}{|c|}{ Rendah } & \multicolumn{2}{|c|}{ Total } \\
\hline & $\mathrm{f}$ & $\%$ & $f$ & $\%$ & $\mathrm{f}$ & $\%$ & $\mathrm{f}$ & $\%$ \\
\hline Salah & 0 & 0 & 0 & 0 & 2 & 6.7 & 2 & 6.7 \\
\hline Tidak & 0 & 0 & 0 & 0 & 4 & 13.3 & 4 & 13.3 \\
\hline Garis besar & 0 & 0 & 19 & 63.3 & 0 & 0 & 19 & 63.3 \\
\hline Lengkap & 5 & 16.7 & 0 & 0 & 0 & 0 & 5 & 16.7 \\
\hline$\sum$ & 5 & 16.7 & 19 & 63.3 & 6 & 20 & 30 & 100 \\
\hline
\end{tabular}

Tabel 6 menunjukkan bahwa sebagian besar sebanyak 19 responden $(63.3 \%)$ dimensi depth (kedalaman materi) pengungkapan diri yang berada dalam kategori sedang adalah secara garis besar. Oleh karena itu hasil penelitian ini tergolong kategori pengungkapan diri sedang yang artinya responden telah mengungkapkan hal - hal yang berkenaan dengan dirinya secara garis 
besar kepada orang lain. Hal ini sejalan dengan penelitian yang dilakukan oleh Nurhayati (2011) yang menemukan bahwa ODHA yang menjalani pendampingan di kelompok Warga
Peduli AIDS (WPA) di Kelurahan Kebon Pisang, Kecamatan Sumur Bandung, Kota Bandung cukup terbuka dengan mengungkapkan dirinya secara garis besar kepada orang lain.

Tabel 7. Distribusi Frekuensi Dimensi Target Person (Sasaran) Pengungkapan Diri Responden

\begin{tabular}{lcccccccc}
\hline \multirow{2}{*}{$\begin{array}{c}\text { Target Person } \\
\text { (sasaran) }\end{array}$} & \multicolumn{9}{c}{ Hasil } & & & \\
\cline { 2 - 10 } & \multicolumn{2}{c}{ Tinggi } & \multicolumn{2}{c}{ Sedang } & \multicolumn{2}{c}{ Rendah } & \multicolumn{2}{c}{ Total } \\
\cline { 2 - 11 } & $\mathrm{f}$ & $\%$ & $\mathrm{f}$ & $\%$ & $\mathrm{f}$ & $\%$ & $\mathrm{f}$ & $\%$ \\
\hline Ayah & 0 & 0 & 4 & 13.3 & 1 & 3.3 & 5 & 16.7 \\
Ibu & 1 & 3.3 & 4 & 13.3 & 0 & 0 & 5 & 16.7 \\
Teman laki - laki & 0 & 0 & 1 & 3.3 & 4 & 13.3 & 5 & 16.7 \\
Teman perempuan & 1 & 3.3 & 4 & 13.3 & 0 & 0 & 5 & 16.7 \\
Pasangan & 3 & 10 & 6 & 20 & 1 & 3.3 & 10 & 33.3 \\
\hline$\sum$ & 5 & 16.7 & 19 & 63.3 & 6 & 20 & 30 & 100 \\
\hline
\end{tabular}

Tabel 7 menunjukkan bahwa sebagian besar sebanyak 6 responden (20\%) dimensi target person (sasaran) pengungkapan diri yang berada dalam kategori sedang adalah pada pasangan. Hasil penelitian di atas selaras dengan penelitian yang dilakukan oleh Suriana \& Dewi (2013) pada pasien ODHA di RSUD Banyumas yang menemukan bahwa ODHA lebih banyak mengungkapkan dirinya kepada pasangannya. Menurut peneliti, hasil penelitian yang menunjukkan sebagian besar responden mengungkapkan dirinya ke pasangan karena mayoritas responden sudah menikah. Jourard (1971) mengungkapkan bahwa orang yang sudah menikah keterbukaan diri (self disclosure) mereka lebih tinggi dan secara lebih mudah mengungkapkan diri dengan pasangan mereka daripada dengan orang lain. 
Tabel 8. Distribusi Frekuensi Pengungkapan Diri Berdasarkan Usia Responden

\begin{tabular}{ccccccccc}
\hline \multirow{2}{*}{ Usia } & \multicolumn{9}{c}{ Pengungkapan Diri (Self Disclosure) } \\
\cline { 2 - 9 } & \multicolumn{2}{c}{ Tinggi } & \multicolumn{2}{c}{ Sedang } & \multicolumn{2}{c}{ Rendah } & \multicolumn{2}{c}{ Total } \\
\cline { 2 - 9 } & $\mathrm{f}$ & $\%$ & $\mathrm{f}$ & $\%$ & $\mathrm{f}$ & $\%$ & $\mathrm{f}$ & $\%$ \\
\hline $20-30$ tahun & 0 & 0 & 6 & 20 & 3 & 10 & 9 & 30 \\
$31-59$ tahun & 5 & 16.7 & 13 & 43.3 & 3 & 10 & 21 & 70 \\
$\geq 60$ tahun & 0 & 0 & 0 & 0 & 0 & 0 & 0 & 0 \\
\hline$\Sigma$ & 5 & 16.7 & 19 & 63.3 & 6 & 20 & 30 & 100 \\
\hline
\end{tabular}

Tabel 8 menunjukkan bahwa sebagian besar responden sebanyak 13 responden (43.3\%) pada rentang usia 31-59 tahun memiliki tingkat pengungkapan diri yang sedang. Hasil penelitian ini sesuai dengan hasil penelitian yang dilakukan oleh Rahmadhaningrum (2013) yang menemukan keterbukaan diri pada usia dewasa madya (25-65tahun) cenderung lebih tinggi daripada usia dewasa lanjut (65-75 tahun).
Menurut peneliti, pengungkapan diri tentang masalah emosional atau hal pribadi lainnya kepada orang lain meningkat pada usia remaja hingga dewasa. Lestarina (2012) menemukan bahwa pengungkapan diri cenderung meningkat seiring dengan meningkatnya usia seseorang. Menurut Devito (2011) pengungkapan diri kepada orang lain meningkat dari usia 17-50 tahun dan kemudian menurun kembali.

Tabel 9. Distribusi Frekuensi Pengungkapan Diri Berdasarkan Jenis Kelamin Responden

\begin{tabular}{|c|c|c|c|c|c|c|c|c|}
\hline \multirow{3}{*}{ Jenis Kelamin } & \multicolumn{6}{|c|}{ Pengungkapan Diri (Self Disclosure) } & & \\
\hline & \multicolumn{2}{|c|}{ Tinggi } & \multicolumn{2}{|c|}{ Sedang } & \multicolumn{2}{|c|}{ Rendah } & \multicolumn{2}{|c|}{ Total } \\
\hline & $\mathrm{f}$ & $\%$ & $f$ & $\%$ & $\mathrm{f}$ & $\%$ & $\mathrm{f}$ & $\%$ \\
\hline Laki- laki & 2 & 6.7 & 8 & 26.7 & 4 & 13.3 & 14 & 46.7 \\
\hline Perempuan & 3 & 10 & 11 & 36.7 & 2 & 6.7 & 16 & 53.3 \\
\hline$\sum$ & 5 & 16.7 & 19 & 63.3 & 6 & 20 & 30 & 100 \\
\hline
\end{tabular}

Tabel 9 menunjukkan bahwa sebagian besar responden sebanyak 11 responden $(36.7 \%)$ yang berjenis kelamin perempuan memiliki tingkat pengungkapan diri yang sedang. Hasil penelitian ini sesuai dengan hasil penelitian sebelumnya yang dilakukan oleh Hargie, Tourish, dan Curtis (2001) menemukan bahwa pengungkapan diri perempuan berbeda dengan laki-laki, dan rata-rata pengungkapan diri pada 
perempuan lebih tinggi dari pada lakilaki.

Pengungkapan diri merupakan salah satu bentuk komunikasi interpersonal yang dalam praktiknya dipengaruhi oleh jenis kelamin pelakunya. Menurut Santrock (2003) perbedaan komunikasi antara laki-laki dan perempuan karena adanya perbedaan budaya pada laki laki dan perempuan yang mencakup perbedaan peran dalam komunikasi yang terjadi saat berhubungan dengan orang lain. Komunikasi antara laki-laki dan perempuan yang berbeda tersebut nampak pula dalam perilaku mengungkapkan diri kepada orang lain. Perbedaan pengungkapan diri antara laki-laki dan perempuan tersebut disebabkan kerena perbedaan peran yang dimiliki keduanya (Jourard, 1964). Menurut Sari dkk (2006) peran yang dimiliki perempuan dan laki-laki disebut sebagai peran ekspresif dan instrumental. Peran ekspresif yang dimiliki perempuan mendukung perempuan untuk mengungkapkan diri kepada orang lain, karena peran tersebut memiliki ciri bercorak sosial, emosional dan bertujuan pada pembentukan hubungan interpersonal. Peran instrumental yang dimiliki oleh laki-laki menghendakinya untuk tidak terlalu bersifat emosional dan banyak membuka diri kepada orang lain.

Menurut Sari, Rejeki, dan Mujab (2006) perbedaan pengungkapan diri antara laki - laki dan perempuan juga disebabkan adanya perbedaan penilaian terhadap pengungkapan diri. Perempuan menilai bahwa hubungan dengan teman akan menjadi lebih dekat jika saling terbuka sehingga bisa saling memahami keadaan masing -masing, sehingga perempuan lebih banyak melakukan pengungkapan diri. Laki - laki cenderung menghindari pengungkapan diri karena memiliki penilaian bahwa pengungkapan diri merupakan tanda kelemahan. Perbedaan tersebut juga disebabkan karena aktivitas waktu luang yang tidak sama antara laki - laki dan perempuan. Berdasarkan pengamatan di lapangan, perempuan lebih banyak mengisi waktu luang dengan bercakap-cakap. Pada dasarnya perempuan menyenangi pembicaraan dengan teman khususnya yang menyangkut masalah pribadi. Laki-laki lebih banyak menghabiskan waktu luang bersama teman dengan melakukan aktivitas bersama daripada melakukan pembicaraan pribadi kepada teman. 


\section{Tabel 10. Distribusi Frekuensi Pengungkapan Diri Berdasarkan Status Perkawinan Responden}

\begin{tabular}{|c|c|c|c|c|c|c|c|c|}
\hline \multirow{3}{*}{ Status Perkawinan } & \multicolumn{6}{|c|}{ Pengungkapan Diri (Self Disclosure) } & & \\
\hline & \multicolumn{2}{|c|}{ Tinggi } & \multicolumn{2}{|c|}{ Sedang } & \multicolumn{2}{|c|}{ Rendah } & \multicolumn{2}{|c|}{ Total } \\
\hline & $\mathrm{f}$ & $\%$ & $f$ & $\%$ & $\mathrm{f}$ & $\%$ & $\mathrm{f}$ & $\%$ \\
\hline Sudah menikah & 5 & 16.7 & 16 & 53.3 & 4 & 13.3 & 25 & 83.3 \\
\hline Belum menikah & 0 & 0 & 3 & 10 & 2 & 6.7 & 5 & 16.7 \\
\hline$\sum$ & 5 & 16.7 & 19 & 63.3 & 6 & 20 & 30 & 100 \\
\hline
\end{tabular}

Tabel 10 menunjukkan bahwa sebagian besar responden sebanyak 16 responden $(53.3 \%)$ yang sudah menikah memiliki tingkat pengungkapan diri yang sedang. Hasil penelitian di atas selaras dengan penelitian yang dilakukan oleh Suriana \& Dewi (2013) pada pasien ODHA di RSUD Banyumas yang menemukan bahwa ODHA lebih banyak mengungkapkan dirinya kepada pasangannya, baik mengenai kehidupan sehari - hari, masalah yang sangat pribadi, atau mengenai status kesehatannya saat ini.

Hasil penelitian tersebut juga selaras dengan yang dikemukakan oleh Jourard (1971) bahwa orang yang sudah menikah keterbukaan diri (self disclosure) mereka lebih tinggi dan secara lebih mudah mengungkapkan diri dengan pasangan mereka daripada dengan orang lain.

\section{SIMPULAN}

Sebagian besar tingkat pengungkapan diri (self disclosure) pada responden adalah tingkat pengungkapan diri sedang sebanyak 19 responden (63.3\%). Sebagian besar pengungkapan diri responden mengenai selera dan minat sebanyak 8 responden $(26.7 \%)$. Sebagian besar responden mengungkapkan tentang dirinya secara garis besar sebanyak 19 responden (63.3\%). Sebagian besar sasaran pengungkapan diri responden adalah ke pasangannya sebanyak 9 responden $(30 \%)$. Sebagian besar responden memiliki tingkat pengungkapan diri sedang pada rentang usia 31 - 59 tahun sebanyak 21 responden (70\%). Sebagian besar responden memiliki tingkat pengungkapan diri sedang berjenis kelamin perempuan sebanyak 11 responden (36.7\%). Sebagian besar responden memiliki tingkat pengungkapan diri sedang adalah responden yang sudah menikah sebanyak 16 responden (53.3\%).

\section{DAFTAR RUJUKAN}

Devito, J. 2011. Komunikasi Antar Manusia. Tanggerang Selatan: Karisma Publishing Group

Dinas Kesehatan Provinsi Bali. 2016. Data Tahunan Dinas Kesehatan 
Provinsi Bali. Denpasar: Dinas Kesehatan Provinsi Bali

Gainau, M. B. 2009. Keterbukaan Diri (Self Disclosure) Siswa dalam Perspektif dan Implikasinya bagi Konseling. Jurnal Ilmiah Widya Warta, Vol. 33. No. 1,18-26.

Hargie, Tourish, dan Curtis. 2001. Adolescence: Gender, Religion, and Adolescence Pattern of Self Disclosure in The Divided Society of Northern Ireland. Tersedia dalam: http://www.findarticles.com/p/articl es/mi_m2248/is_144_36/ai_847226 92/ pg1_2_3_4. Diakses: 10 Juni 2016.

Hemawati, P. 2009. Keterbukaan Diri Orang Dengan HIV/AIDS (ODHA). Skripsi. Yogyakarta: Universitas Muhammadiyah

Hermawati, P. 2011. Hubungan Persepsi ODHA Terhadap Stigma HIV/AIDS Masyarakat Dengan Interaksi Sosial Pada ODHA. Skripsi. Jakarta: Universitas Islam Negeri Syarif Hidayatullah

Jourard, S. M. 1971. The Transparent Self: Self Disclosure and WellBeing. New York: Van Nostrand Reinhold Company.

Metronews.com. 2015. Jumlah Kasus HIV \& AIDS di Indonesia
Meningkat. tersedia dalam http://news.metrotvnews.com $/ \mathrm{read} / 2$ 015/11/30/196222/jumlah-kasushiv-aids-di-indonesia-meningkat. diakses tanggal 2 Januari 2016

Nurhayati, I. 2011. Hubungan Pengungkapan Diri: Self Disclosure dan Tipe Kepribadian dengan Tingkat Stress Skripi. Bandung: Universitas Pendidikan Indonesia

Rahmadhaningrum, A. 2013. Hubungan Keterbukaan Diri (Self Disclosure) Dengan Interaksi Sosial. Skripsi. Yogyakarta: STIKES Aisyiyah Yogyakarta

Sari, Rejeki, dan Mujab. 2006. Pengungkapan Diri Mahasiswa Tahun Pertama Universitas Diponegoro Ditinjau Dari Jenis Kelamin Dan Harga Diri. Jurnal Psikologi Universitas Diponegoro Vol.3 No. 2, 40-48.

Suriana \& Dewi. 2013. Self Disclosure Pasien ODHA RSUD Banyumas. Psycho Idea Tahun 11 No.1, 5674.

WHO. 2015. HIV/AIDS. tersedia dalam http://www.who.int/mediacentre/fa ctsheets/fs360/en/. diakses tanggal 2 Januari 2016 
